\title{
Gastrointestinal Parasites in Free-Range Chicken Raised under Extensive System from the Northeast of Brazil
}

-Author(s)

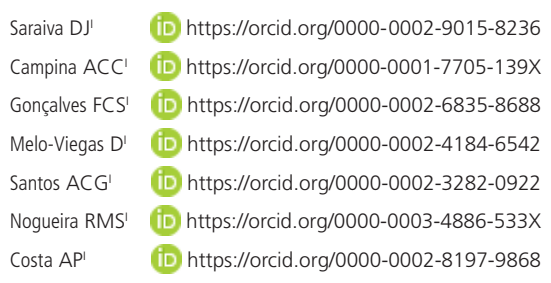

Laboratório de Parasitologia-Universidade Estadual do Maranhão, São Luís, Maranhão, Brasil.

\section{-Mail Address}

Corresponding author e-mail address Dra. Andréa Pereira da Costa

Universidade Estadual do Maranhão, Cidade Universitária Paulo VI, Avenida Lourenço

Vieira da Silva $n^{\circ} 1000$, Jardim São Cristovão, São Luís-MA, Brasil, CEP 65055310.

Phone: 550989 9191-1228

Email: andrea.costa@professor.uema.br

\section{aKeywords}

Cestoda, economics, Gallus gallus domesticus, helminthe fauna, nematoda.

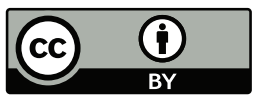

Submitted: 12/June/2020 Approved: 22/November/2020

\section{ABSTRACT}

Brazilian poultry production is growing, mainly due to the cost and benefit that chicken meat provides. The importance of freerange chickens and the susceptibility, to which they are exposed, makes it necessary to know about gastrointestinal parasites and the consequences that large infections can cause for them as such as weight loss. The present study aimed to determine the occurrence of gastrointestinal parasites in free-range hens raised in an extensive regime in the municipality of Santa Rita, state of Maranhão, Brazil. The studied population was composed of adult chickens (Gallus gallus domesticus) acquired from slaughterhouses in the region. The gastrointestinal organs of each chicken were separated and subsequently conditioned in flasks containing Railliet and Henry's solution and sent to the laboratory, to be analyzed and processed. Of the 100 chickens examined, 227 specimens of helminthes were identified, with a frequency of $32.6 \%$ for nematodes and $67.4 \%$ for cestodes. Among the nematode the following parasites were identified: Ascaridia galli (27.03\%); Heterakis gallinarum (48.65\%) and Subulura spp. (24, 32\%). Raillietina echinobothrida (100\%) was the only cestoda identified. The average infection rate by species of parasite was 1.18 for A. galli, 2.22 for H. gallinarum, 1.06 for Subulura spp. and 9.00 for R. echinobothrida. It is concluded that free-range chickens are parasitized by nematodes and cestoda.

\section{INTRODUCTION}

Brazilian poultry production is growing, mainly due to the cost and benefit that chicken meat provides. Alongside that the alternative raising of free-range chicken is getting importance in the market (Associação Brasileira da Avicultura Alternativa, 2018).

The governmental program "More Production" of the State of Maranhão, Brazil has the objective to promote de economic empowerment of the production chains in different scales, adding value to the products from Maranhão State, leading to richness, employments and income. In this context we found the production chain of free-range chicken in the municipality of Santa Rita, where this study was done.

The rising of free-range chicken is an important activity in rural proprieties and smallholder farms of the Northeastern of Brazil. However, lack of technical assistance makes an efficient management of the animals difficult and the parasitism could lead to loss of appetite, low food conversion and decrease in meat and egg production (lqbal et al., 2018; Van et al., 2019).

The actual importance of free-range chicken production makes the knowledge about gastrointestinal parasites and the consequence that severe infections can bring to the productivity of these animals necessary (Yevstafyeva et al., 2018). 
Saraiva DJ, Campina ACC, Gonçalves FCS, Melo-Viegas D, Santos ACG, Nogueira RMS, Costa AP
Gastrointestinal Parasites in Free-Range Chicken Raised under Extensive System from the Northeast of Brazil
This study aimed to evaluate the prevalence of gastrointestinal parasites in free-range chicken (Gallus gallus domesticus) kept under extensive conditions in the municipality of Santa Rita, State of Maranhão, Brazil as a mean to generate scientific knowledge that could provide contributions to this production chain within the scope of the "More Production" governmental program.

\section{MATERIAL AND METHODS}

This study was conducted in the municipality of Santa Rita, Maranhão State, Brazil, located in the coordinates $03^{\circ} 08^{\prime} 37^{\prime \prime S}$ and $44^{\circ} 19^{\prime} 33^{\prime \prime} \mathrm{W}$. The climate is subtropical humid, the mean annual temperature is above $24^{\circ} \mathrm{C}$ (Geplan, 2002; lbge, 2018).

The study was carried out from September/2016 to January/2017. The sample was defined for convenience and comprised by 100 free-range chickens (Gallus gallus domesticus). The animals were raised under extensive conditions. During the daytime, they were allowed to scavenge for edible insects, seeds, and pasture. During the night, they were perched on the trees, as informed by the owners.

The gastrointestinal tract of each animal was collected after slaughter, put on vials containing Railliet \& Henry solution (Amato et al., 1991) for further examination, to search for helminthes.

The collected helminthes were screened and mounted according to Amato et al. (1991) and the species were identified according to the description given by Vicente et al. (1995).

This research was approved by the Ethics Commite of the State University of Maranhão (Process $n^{\circ}$. 31/2017).

\section{RESULTS AND DISCUSSION}

In free-range/backyard poultry production system, the species of helminthes involved are more or less the same, but different numbers were reported by different investigators (Uhuo et al., 2013; Maina et al., 2017; Win et al., 2020). A total of 227 specimens of helminthes were collected from the gastrointestinal tract, $74(32.6 \%)$ nematodes and $153(67.4 \%)$ cestodes. None of the birds harbored trematodes. Nematodes Ascaridia galli (20/27.03\%) Heterakis gallinarum $(36 / 48.65 \%)$ and Subulura spp (18/24.32\%) and the cestode Raillietina echinobothrida (153/100\%) were recovered (Table 1). Except for Subulura, the other parasites identified in the present study are commonly reported in the literature (Luka \& Ndams, 2007; Ekpo et al, 2010; Rayyan et al., 2010; Uhuo et al., 2013; Tomza-Marciniak, 2014; Wuthijaree et al., 2019). Win et al. (2020) identified Subulura brumpti (2.0\%) in fecal samples of free-range chickens.

Table 1 - Helminth species infecting chicken free-range hens raised in an extensive regime in the municipality of Santa Rita, state of Maranhão, Brazil.

\begin{tabular}{lcc}
\hline Helminth species & $\begin{array}{c}\text { No. of infected chicken/ } \\
\text { nematodes or cestodes }\end{array}$ & $\begin{array}{c}\text { Percentage } \\
\%\end{array}$ \\
\hline Ascaridia galli & $20 / 74$ & 27.03 \\
Heterakis gallinarum & $36 / 74$ & 48.65 \\
Subulura spp. & $18 / 74$ & 24.32 \\
Raillietina echinobothrida & $153 / 153$ & 100 \\
\hline Total & 227 & 100 \\
\hline
\end{tabular}

In Brazil we can mention the work of Costa et al. (1986) that published a literature review and described 50 species of helminthic parasites of chickens' occurrence in Brazilian states and territories. Afterwards, works were published in the States of Rio de Janeiro (D'Avila et al., 2004; Gomes et al., 2009), Paraná, (Vieira, 2010), São Paulo (Silva et al., 2016) and so on, and also pointed out Ascaridia galli, Heterakis gallinarum and Railleitina as frequent parasites in chicken. However, chickens can present a diversity of nematode, cestoda and trematoda helminthes as reported by Silva et al. (2018) when studying helminthic infections in chickens (Gallus domesticus) raised indifferent production systems in Brazil

Related to the sex of the parasites we had: $40 \%$ female and $60 \%$ male of $A$. galli, 36.11\% female and $63.89 \%$ males of $H$. gallinarum and $72.22 \%$ female and $27.78 \%$ male of Subulura spp. The mean infection rate was as follows: $1.18 ; 2.22 ; 1.06 ; 9.00$ for $A$. galli, H. gallinarum, Subulura spp., R. echinobothrida, respectively.

From the total of examined chicken, $8 \%$ were parasitized by $A$. galli, differing from other reports that pointed out a prevalence varying from $69,5 \%$ to 100\% (Permin et al., 2002; Thapa et al., 2015). But Iqbal et al. (2018), as we did, found out a prevalence of $9 \%$. Differences could probably be due to the type of rearing system as intensive system tends to favor the presence of parasite of short cycle and direct transmission where the litter is an ideal place for the development of the eggs of $A$. galli (Ruff, 1999; Iqbal et al., 2018). It is important to mention that high prevalence of $A$. galli in hen farming is partly because of a deficient management and there is no immunity from hens to chicks, as stated by Rahimian et al. (2017). Besides, Ascaridia galli causes stunted growth, low productivity, irritation and inflammation 
Saraiva DJ, Campina ACC, Gonçalves FCS, Melo-Viegas D, Santos ACG, Nogueira RMS, Costa AP
Gastrointestinal Parasites in Free-Range Chicken Raised under Extensive System from the Northeast of Brazil of the mucosa thus interfering with the absorption of food (UHUO, et al. 2013), so in severe infections can become a problem.

In this study, from the total of chickens it was observed that $2 \%$ were parasitized by $H$. gallinarum. Higher results were found by Thapa et al. (2015) who obtained a global mean prevalence of $29.0 \%$ in European countries with great variation among countries. In Brazil, this parasite was the most common species diagnosed in Gallus gallus in different regions of São Paulo State (Silva et al., 2016).

$H$. gallinarum has indirect biological cycle and its intermediate hosts are earthworm and insects, in which the eggs of the parasite remain viable. Chickens get infection by eating the intermediate hosts. This species of parasite could lead to typhlitis, diarrhea and weight loss (Yevstafyeva et al., 2018; Ola-Fadunsin et al., 2019). Uhuo et al. (2013) calls attention to this species because it can also act as a carrier of Histomonas meleagridis in turkeys and chickens.

Subulura had $9 \%$ of prevalence of the total of chicken sampled, whereas lqbal et al. (2018) detected $14 \%$ of Subulura brumpti and Ola-Fadunsin et al. (2019) $0,4 \%$ of S. brumpti in fecal samples. Variations could be due to rearing systems since the intensive one has better treatment in terms of biosecurity, hygiene, and food when compared to the extensive one (OlaFadunsin et al., 2019).

The infection by cestoda was of $10 \%$ of the total of the sampled animals and was represented exclusively by Raillietina echinobothrida. This parasite genus and its species are reported in many parts of the world, including in Brazil, presenting different prevalence (Costa et al., 1975; Costa et al., 1986; Gomes 2009; Ibqal et al. 2018, Win et al., 2020).

Species of Raillietina need intermediate hosts (gastropod mollusk and ants) to complete the biological cycle. Therefore, differences in prevalence can be associated to the quantity of available intermediate hosts, hygiene and local climate (Costa et al., 1986; Ibqal et al., 2018).

Intestinal nodules and severe hemorrhagic enteritis due to deep penetration of the parasite in the intestinal mucosa and submucosa of the host was observed here as reported by Silva et al. (2005) in cases of Raillietina magninumida infection and Vieira et al. (2010) detected intestinal tissue injury in chicken infected by R. echinobotrida. In fact, R. echinobothrida induces the formation of nodules in the intestinal wall, which can lead to confusion with lesions of avian tuberculosis (Saif et al., 2003).
The genus Raillietina is considered of great pathogenicity among the cestoda of chickens and it has been associated to $50 \%$ of mortality in the same hen farms.

It is important to emphasize that chickens reared in extensive systems satisfy their nutrient requirement by roaming from place to place and they usually seek for food in the superficial layers of the soil that is often contaminated with parasite eggs and larva, as well as various insects or earthworm that serve as paratenic or intermediate hosts for internal parasites that infest poultry (Puttalakshmamma et al., 2008). Therefore, free-ranging birds have an increased opportunity to encounter the infective eggs, larvae, and intermediate hosts of parasites that can cause serious debilitating infections (Wilson et al., 1987; Aini, 1990). In this sense, Afolabi et al. (2016) observed in their studies that the highest prevalence of gastrointestinal infection was recorded among the chickens that were kept in an extensive management system, while the lowest prevalence was recorded among the chickens kept in an intensive management system.

\section{CONCLUSION}

It is concluded that free-range chicken from Santa Rita are infected by helminthes. Ascaridia galli, Heterakis gallinarum, Subulura spp. and Raillietina echinobothrida are for the first time reported in this host in the State of Maranhão. Although the prevalence was not high it is recommended hygiene measures in order to avoid severe parasite loads that could cause injury to the animals and compromise production.

\section{ACKNOWLEDGMENTS}

The authors wish to thank the professional of Santa Rita slaughterhouses, Fundação de Amparo à Pesquisa e ao Desenvolvimento Científico e Tecnológico do Maranhão/FAPEMA and this study was finaced in part by the Coordenação de Aperfeiçoamento de Pessoal de Nível Superior - Brasil (CAPES) - Finance code 001.

\section{REFERENCES}

Aini, I. Indigenous chicken production in South-east Asia. World's Poultry Science Journal 1990;46(1):51-57.

Afolabi OJ, Simon-Oke IA, Olasunkanmi AO. Intestinal Parasites of Domestic Chicken (Gallus gallus domesticus) in Akure, Nigeria. Journal of Biomedicine 2016;1(4):1-4

Amato JFR, Boeger WA, Amato SB. Protocolos para laboratório:coleta e processamento de parasitos de pescado. Rio de Janeiro: Imprensa Universitária UFRRJ; 1991. 
Saraiva DJ, Campina ACC,

Gonçalves FCS, Melo-Viegas D,

Santos ACG, Nogueira RMS, Costa AP
Gastrointestinal Parasites in Free-Range Chicken Raised under Extensive System from the Northeast of Brazil
Associação Brasileira da Avicultura Alternativa. Galinha caipira [cited 2019 Set 06]. Avaliable from: aval.org.br/pagina.php?post_id=31

Costa HMA, Leite ACR, Guimarães MP, Lima WS. Distribuição de helmintos parasitos de animais domésticos no Brasil. Arquivo Brasileiro de Medicina Veterinária e Zootecnia 1986;38:465-579.

Costa JC, Guimarães MP, Grisi L, Barros GC. Helmintos parasitos de Gallus gallus domesticus (L.) no litoral sul do Espírito Santo - Brasil. Arquivos da Escola de Veterinária da UFMG 1975;27:45-46.

D'Ávila SDRJP, Bessa ECA, Rodrigues MLA. Exame parasitológico de fezes para o diagnóstico de helmintoses de galinhas (Gallus gallus Linnaeus, 1758) criadas em sistema semi-extensivo:avaliação das técnicas de sedimentação e de flutuação simples. Revista Brasileira de Parasitologia Veterinária 2004;13(Suppl):263.

Ekpo UF, Ogbooye AA, Oluwole AS, Takeet M. A preliminary survey on the parasites of free range chicken in Abeokuta, Ogun state, Nigeria. Journal of Natural Sciences, Engineering and Technology 2010;9(2):123-130.

Silva GS, Romera DM, Conhalato GS, Soares VE, Meireles MV. Helminth infections in chickens (Gallus domesticus) raised in different production systems in Brazil. Veterinary Parasitology: Regional Studies and Reports 2018; 12:55-60.

Gomes FF, Machado HHS, Lemos LS, Almeida LG, Daher RF. Principais parasitos intestinais diagnosticados em galinhas domésticas criadas em regime extensivo na municipalidade de Campos dos Goytacazes, RJ. Ciência Animal Brasileira 2009;10(3):818-822.

IBGE - Instituto Brasileiro de Geografia e Estatística. Cidades e estados, Santa Rita, Maranhão, 2018 [cited 2019 Set 02]. Avaliable from: ibge. gov.br/cidades-e-estados/ma/santa-rita.html.

Iqbal RZ, Adnan A, Abdullah A, Ahmed SN, Ambreen L. Comparing git cestodes and nematodesin desi and broiler chicken. University of Sindh Journal of Animal Sciences 2018;2(3):42-47

Luka SA, Ndams IS. Gastrointestinal parasites of domestic chicken Gallus gallus domesticus linnaeus 1758 In Samaru, Zaria Nigeria. Science World Journal 2007;2(1):27-29.

Maina AN, Waruiru RM, Mbuthia PG, Munyua WK, Otieno RO, Mutune MN. Prevalence of gastrointestinal parasites in indigenous chickens slaughtered at live bird markets of Nairobi County, Kenya. Livestock Research for Rural Development 2017;29(233).

GEPLAN - Gerência de Estado e Planejamento e Gestão. Atlas do Maranhão. São Luís: Universidade Estadual do Maranhão; 2002. p.39.

Ola-Fadunsin SD, Uwabujo PI, Sanda IM, Ganiyu IA, Hussain K, Rabiu M, et al. Gastrointestinal helminths of intensively managed poultry in Kwara Central, Kwara State, Nigeria:Its diversity, prevalence, intensity, and risk factors. Veterinary World 2019;12(3):389-396.

Permin A, Esmann JB, Hoj CH, Hove T, Mukaratirwa S. Ecto-, endo- and haemoparasites in free-range chickens in the Goromonzi District in Zimbabwe. Preventive Veterinary Medicine 2002;54:213-224.

Puttalakshmamma GC, Ananda KJ, Prathiush PR, Mamatha GS, Rao S. Prevalence of gastrointestinal parasites of poultry in and around Bangalore. Veterinary World 2008;7(1):201-202

Rahimian S, Daş G, Gauly M. Maternal protection against Ascaridia galli?. Veterinary Parasitology 2017;233:43-47.
Rayyan R, Al-Hindi, Al-Zain B. Occurrence of gastrointestinal helminthes in commercial and free-range chickens in Gaza strip, Palestine. Egypt Poultry Science 2010;30(2):601-606.

Ruff, MD. Important parasites in poultry productionsystems. Veterinary Parasitology 1999;84(3/4):337-347.

Saif YM, Faldy AM, Calnex BW, Beard CW, Swagyne DE, Barnels HJ, et al. Disease of poultry. $11^{\text {th }}$ ed. lowa: lowa State Press; 2003.

Silva GS, Romera DM, Fonseca LEC, Meireles MV. Helminthic parasites of chickens (Gallus Domesticus) in different regions of São Paulo State, Brazil. Brazilian Journal of Poultry Science 2016;18(1):163-168.

Silva MEM, Mattos JDG, Tortelly R, Menezes RC. Lesões causadas por alguns helmintos em galinhas d'angola (Numida meleagris) procedentes do estado do Rio de Janeiro. Revista Brasileira de Ciência Veterinária 2005;12(1/3):118-123.

Tomza-Marciniak A, Pilarczyk B, Tobiańska B, Tarasewicz N. Gastrointestinal parasites of free-range chickens. Annals of Parasitology 2014, 60(4):305-308

Thapa S, Hinrichsen LK, Brenninkmeyer C, Gunnarsson S, Heerkens JL, Verwer $C$, et al. Prevalence and magnitude of helminth infections in organic laying hens (Gallus gallus domesticus) across Europe. Veterinary Parasitology 2015;214(1/2):118-124

Uhuo AC, Okafor FC, Odikamnoro OO, Onwe CS, Abarike, MC, Elom JN. Common gastrointestinal parasites of local chicken (Gallus domesticus) slaughtered in some selected eatery centres in Abakaliki, Ebonyi State: implication for meat quality. International Journal of Development and Sustainability 2013;2(2):1416-1422.

Van NT, Cuong NV, Yen NT, Nhi NT, Kiet BT, Hoang NV, et al. Characterization of gastrointestinal helminths and their impact in commercial smallscale chicken flocks in the Mekong Delta of Vietnam. Tropical Animal Health and Production 2019;52:53-62.

Vicente JJ, Rodrigues HO, Gomes DC, Pinto RB. Nematóides do Brasil. Parte IV: nematóides de aves. Revista Brasileira de Zoologia 1995;12(1):1273.

Vieira FEG. Helmintofauna em frangos (Gallus gallus domesticus Linnaeus, 1758) criados em sistema colonial/caipira na região norte do estado do Paraná [dissertation]. Londrina (PR): Universidade Estadual de Londrina; 2010.

Yevstafyeva VA, Melnychuk VV, Nikiforova OV, Suprunenko KV, Korchan LN, Lokes-Krupka TP, et al. Comparative morphology and biology of nematodes of genus Heterakis (Nematoda, Heterakidae), parasites of the domestic goose (Anser anser) in Ukraine. Regulatory Mechanisms in Biosystems 2018;9(2):229-236.

Wuthijaree K, Lambertz C, Vearasilp T, Anusatsananun V, Gauly M. Prevalence of gastrointestinal helminths in thai indigenous chickens raised under backyard conditions in Northern Thailand. Journal of Applied Poultry Research 2019;28(1):221-229.

Wilson RT, Traore A, Kuit HG, Slingerland M. Livestock production in central Mali: reproduction, growth and mortality of domestic fowl under traditional management. Tropical Animal Health Production 1987;19:229-236. 